\title{
Perkembangan Wilayah dan Perubahan Tutupan Lahan di Kabupaten Purwakarta sebagai Dampak dari Proses Konurbasi Jakarta-Bandung
}

\author{
Regional Development and Land Cover Change in Purwakarta Regency \\ as an Impact of Jakarta-Bandung Conurbation Process
}

\author{
Alfin Murtadho $^{1^{*}}$, Siti Wulandari ${ }^{2}$, Muhammad Wahid ${ }^{3} \&$ Ernan Rustiadi $^{1}$ \\ ${ }^{1}$ Pusat Pengkajian Perencanaan dan Pengembangan Wilayah (P4W) LPPM - Institut Pertanian Bogor, \\ Kampus IPB Baranangsiang, Jalan Raya Pajajaran, Bogor 16127, Indonesia; ${ }^{2}$ Program Studi Ilmu \\ Perencanaan Wilayah, Sekolah Pascasarjana, Institut Pertanian Bogor, Jalan Meranti, Kampus IPB Dramaga, \\ Bogor 16680, Indonesia; ${ }^{3}$ Program Studi Manajemen Sumberdaya Lahan, Fakultas Pertanian, Institut \\ Pertanian Bogor, Jalan Meranti Kampus IPB Dramaga, Bogor 16680, Indonesia; \\ *Penulis Korespondensi. e-mail: alfin_pwl@apps.ipb.ac.id \\ (Diterima: 25 Maret 2018; Disetujui: 2 Juni 2018)
}

\begin{abstract}
Jabodetabek and Bandung Raya metropolitan region experienced an urban expansion phenomenon that caused the two metropolitan regions to become increasingly connected by a corridor and form a mega-urban region caused by the conurbation process. Purwakarta regency is one of the regions in Jakarta-Bandung corridor that experienced the impact of Jakarta-Bandung conurbation process. This study aims to analyze the level of regional development, to analyze land cover change that occurred, and to predict Purwakarta Regency land uselland cover in 2030. Regional development analysis is done by using the Scalogram method based on Potential Village data of year 2003 and 2014. Land cover change analysis is done through spatial analysis by overlaying land cover Landsat Satellite Image of year 2000 and 2015. Land use/land cover prediction in 2030 is conducted through spatial modelling of Cellular Automata Markov method. Purwakarta Regency experienced an increase in regional development within the period of 11 years (2003 to 2014), which is marked by a decrease in the percentage of the number of villages that are in hierarchy III and increase in the percentage of the number of villages that are in hierarchy II and I. In general, within 15 years (2000 to 2015) Purwakarta Regency has increasing number of built-up area and mixed gardens, meanwhile dry land, forest, paddy field, and water bodies tend to decrease. The results of CA Markov analysis show that the built-up area is predicted to continue to increase from 2000 to 2030, meanwhile paddy fields and water bodies will continue to decrease.
\end{abstract}

Keywords: built-up area, conurbation, land cover change, regional development

\begin{abstract}
ABSTRAK
Wilayah metropolitan Jabodetabek dan Bandung Raya mengalami fenomena urban expansion yang menyebabkan kedua wilayah metropolitan tersebut semakin lama semakin terhubung oleh suatu koridor dan membentuk suatu wilayah mega-urban yang disebabkan oleh proses konurbasi. Kabupaten Purwakarta yang merupakan salah satu wilayah pada koridor JakartaBandung mengalami dampak dari proses konurbasi Jakarta-Bandung. Penelitian ini bertujuan untuk menganalisis tingkat perkembangan wilayah, perubahan tutupan lahan yang terjadi serta memprediksi penggunaan/penutupan lahan di Kabupaten Purwakarta pada tahun 2030. Analisis
\end{abstract}


perkembangan wilayah dilakukan dengan menggunakan metode Skalogram berdasarkan data Potensi Desa tahun 2003 dan 2014. Analisis perubahan tutupan lahan dilakukan dengan menumpangtindihkan Citra Landsat tutupan lahan tahun 2000 dan 2015. Prediksi penggunaan/ penutupan lahan tahun 2030 dilakukan dengan metode permodelan Cellular Automata Markov. Kabupaten Purwakarta mengalami peningkatan perkembangan wilayah dalam kurun waktu 11 tahun (2003 hingga 2014) yang ditandai dengan menurunnya persentase jumlah desa yang berhierarki III dan meningkatnya persentase jumlah desa yang berhierarki II dan I. Secara umum, dalam kurun waktu 15 tahun (2000 hingga 2015) Kabupaten Purwakarta mengalami peningkatan luas tutupan lahan terbangun dan kebun campuran, sedangkan lahan terbuka, hutan, sawah dan badan air mengalami penyusutan luas. Hasil analisis CA Markov menunjukkan bahwa lahan terbangun diprediksi akan terus mengalami peningkatan luas dari tahun 2000 hingga 2030, sedangkan lahan sawah dan badan air akan terus mengalami penyusutan luas.

Kata kunci: lahan terbangun, konurbasi, perkembangan wilayah, perubahan tutupan lahan

\section{PENDAHULUAN}

Wilayah dapat diartikan sebagai suatu kesatuan sistem yang terdiri atas bagian-bagian yang memiliki keterkaitan, ketergantungan dan saling berinteraksi satu sama lain serta tidak dapat dipisahkan (Rustiadi et al., 2011). Seluruh wilayah Jakarta memiliki ketergantungan dan saling berinteraksi dengan wilayah Bogor, wilayah Depok, wilayah Tangerang Selatan dan wilayah Bekasi sehingga terbentuk wilayah metropolitan Jabodetabek. Hal serupa terjadi dengan wilayah Kota Bandung yang memiliki ketergantungan dan saling berinteraksi dengan Kota Cimahi, Kabupaten Bandung dan Kabupaten Bandung Barat sehingga terbentuk wilayah metropolitan Bandung Raya.

Wilayah metropolitan Jabodetabek dan Bandung Raya mengalami fenomena urban expansion atau peningkatan kawasan terbangun secara cepat yang disebabkan oleh proses urbanisasi dan suburbanisasi. Fenomena ekspansi ini ditandai oleh peningkatan kawasan terbangun yang menyebar keluar dari pusat kota ke pinggiran kota hingga menyebabkan peningkatan perkembangan ekonomi dan aktivitas perkotaan (Pravitasari et al., 2015). Fenomena urban expansion ini menyebabkan wilayah metropolitan Jabodetabek dan Bandung Raya semakin lama semakin terhubung menjadi suatu wilayah mega-urban oleh suatu koridor. Wilayah mega-urban ini dinamakan Jakarta-Bandung Mega-Urban Region atau JBMUR (Dorodjatoen, 2009). Terbentuknya wilayah mega-urban JBMUR ini disebabkan oleh proses konurbasi. Konurbasi menurut Peraturan Menteri Pekerjaan Umum Nomor 494 tahun 2005 tentang Kebijakan dan Strategi Nasional Pengembangan Perkotaan, merupakan proses terjadinya perkembangan fisik perkotaan yang mengakibatkan bergabungnya suatu wilayah metropolitan dengan wilayah-wilayah di sekitarnya sehingga terbentuk wilayah metropolitan yang lebih besar.

Menurut Laquian (2008) dalam Wilonoyudho (2010), pada tahun 2010 terdapat 12 megacity (mega-urban) di Asia yang terbagi menjadi 3 jenis, yaitu: 1) Urban Corridors, seperti Tokyo-Yokohama-Nagoya-OsakaKobe-Kyoto Shinkansen (bullet train corridor) di Jepang dan Beijing-Tianjin-TangshanQinhuangdao (transport corridor) di Tiongkok; 2) Megacity yang didominasi wilayah perkotaan, seperti Metro Manila di Filipina dan Dhaka Metropolitan di Bangladesh; 3) Subnational City Cluster, seperti wilayah Surabaya-Surakarta-Semarang-YogyakartaMalang di Indonesia dan wilayah Daegu-UlsanBusan-Guangjiu di Korea Selatan. Mega-urban di Asia ini mengalami pertumbuhan penduduk rata-rata yang sangat tinggi, yaitu sebesar $2.4 \%$ per tahun. Perkembangan JBMUR di Indonesia termasuk ke dalam jenis Urban Corridors karena merupakan suatu proses perkembangan 
perkotaan akibat tingginya urbanisasi yang terhubung melalui suatu infrastruktur perkotaan atau koridor.

Proses konurbasi Jakarta-Bandung dicirikan dengan meningkatnya pertumbuhan penduduk, terjadinya peningkatan aktivitas pada berbagai sektor dan berkembangnya kawasan terbangun yang terhubung dengan jaringan jalan akses penghubung atau koridor pada kedua wilayah metropolitan ini yaitu jalur Bogor-Puncak-Cianjur-Bandung dan jalan tol Cipularang (Saifullah et al., 2017). Proses konurbasi juga terjadi pada wilayah Kuala Lumpur akibat tingginya pertumbuhan penduduk, ekspansi spasial dan pertumbuhan ekonomi dalam beberapa dekade hingga membentuk Kuala Lumpur Metropolitan Area (KLMA) yang terus meluas karena terhubung melalui southern corridor dengan Multimedia Super Corridor (MSC) zone (Bunnel et al., 2002).

Kabupaten Purwakarta merupakan salah satu wilayah pada koridor Jakarta-Bandung. Menurut Giyarsih (2012), terbentuknya koridor yang menghubungkan dua kota besar (antarkota) akan menyebabkan semakin kaburnya (blurring) sifat perdesaan dan semakin kuatnya sifat perkotaan pada wilayah koridor. Wilayah-wilayah perdesaan di koridor antarkota akan mengalami transformasi struktur wilayah atau disebut juga sebagai proses kotadesasi dimana struktur wilayah agraris akan berubah menjadi struktur non-agraris.

Terdapat beberapa koridor antarkota di Pulau Jawa adalah Koridor Jakarta-CirebonSemarang, Koridor Jakarta-Bandung, Koridor Semarang-Surakarta-Yogyakarta dan Koridor Surabaya-Malang. Terbentuknya koridor ini menyebabkan berkembangnya daerah-daerah di sepanjang koridor atau wilayah koridor. Wilayah koridor merupakan suatu wilayah pada jalur yang menghubungkan dua kota besar akibat proses konurbasi. Wilayah-wilayah di sepanjang jalan yang menghubungkan dua kota besar tersebut tidak teridentifikasi sebagai daerah yang sudah berkembang secara fisik. Seiring berjalannya waktu, wilayah koridor tersebut akan mengalami transformasi spasial, ekonomi, sosial dan kultural sehingga cenderung mengalami transformasi struktur wilayah (Giyarsih, 2012).

Proses transformasi struktur wilayah menuju sifat perkotaan akan berpengaruh pada peningkatan kebutuhan akan lahan akibat semakin tingginya pertumbuhan penduduk baik secara fertilitas, mortalitas maupun migrasi (Abror et al., 2016). Meningkatnya kebutuhan akan lahan tersebut menyebabkan terjadinya proses alih fungsi lahan, terutama alih fungsi dari lahan bervegetasi menjadi lahan-lahan terbangun (Pravitasari et al., 2018). Semakin meningkatnya jumlah penduduk dan berbagai aktivitas pada suatu wilayah, akan mendorong terjadinya penambahan jumlah dan jenis fasilitas yang berakibat pada terjadinya perkembangan wilayah.

Wilayah koridor merupakan bentuk ekspresi keruangan penjalaran kota ke luar batas yuridis administratif mengikuti jalur aksesibilitas (transportasi) hingga menjangkau daerah perdesaan (hinterland) atau kota lain. Pada wilayah ini, tingkat aksesibilitas menjadi faktor yang paling kuat mempengaruhi aktivitas penduduk yang akhirnya akan mempercepat perkembangan wilayah (Giyarsih, 2012). Berdasarkan latar belakang yang telah disebutkan, muncul suatu pertanyaan penelitian "apakah Kabupaten Purwakarta sebagai salah satu wilayah koridor JBMUR mengalami tingkat perkembangan wilayah yang cukup tinggi?". Sehingga tujuan penelitian ini adalah: (1) menganalisis tingkat perkembangan wilayah Kabupaten Purwakarta tahun 2003 hingga 2014; (2) menganalisis perubahan tutupan lahan yang terjadi di Kabupaten Purwakarta; serta (3) memprediksi penggunaan/ penutupan lahan di Kabupaten Purwakarta pada tahun 2030.

\section{METODOLOGI}

\section{Jenis dan Sumber Data}

Penelitian ini menggunakan data sekunder, yaitu Citra Landsat tutupan lahan wilayah penelitian tahun 2000, 2005 dan 2015 yang bersumber dari Pusat Penelitian 
Lingkungan Hidup IPB, peta batas administrasi wilayah penelitian yang bersumber dari Badan Pusat Statistik dan Potensi Desa Jawa Barat tahun 2003 dan 2014 yang bersumber dari Badan Pusat Statistik. Lokasi dari penelitian ini adalah di Kabupaten Purwakarta, Provinsi Jawa
Barat yang berbatasan dengan Kabupaten Karawang di bagian Utara, Kabupaten Subang di bagian Timur, Kabupaten Bandung Barat di bagian Selatan serta Kabupaten Bogor dan Kabupaten Cianjur di bagian Barat.

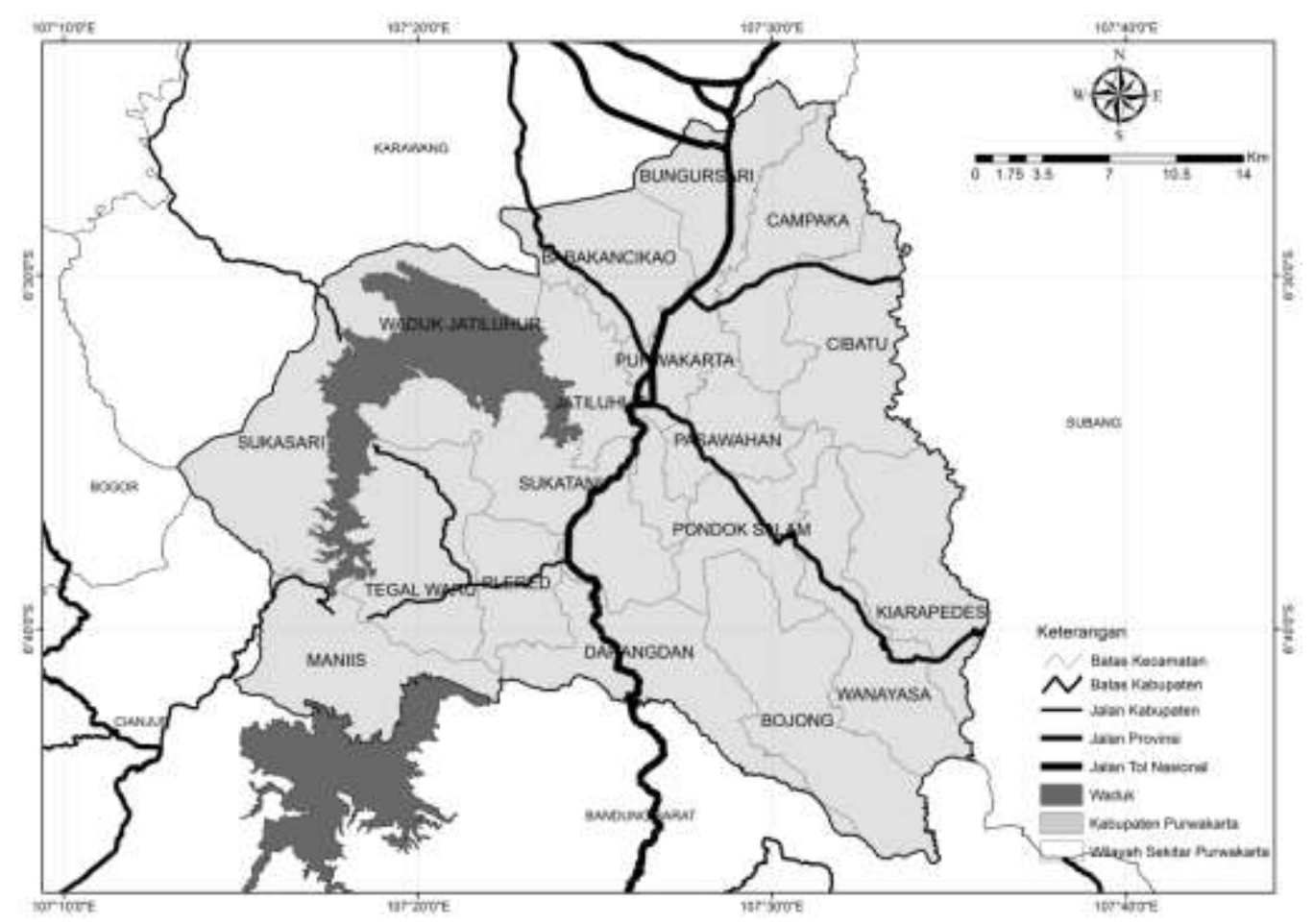

Gambar 1. Peta Administrasi Wilayah Penelitian Sumber: Badan Pusat Statistik, 2010.

\section{Analisis Perkembangan Wilayah}

Analisis perkembangan wilayah dilakukan dengan menggunakan metode skalogram sebagaimana telah dilakukan dalam penelitian-penelitian sebelumnya terkait perkembangan wilayah (Sitorus et al., 2012; Ekosafitri et al., 2017). Metode skalogram berfungsi untuk melihat gambaran tingkat perkembangan pada suatu wilayah secara administratif berdasarkan pada data jarak aksesibilitas, jumlah dan jenis fasilitas umum serta jumlah penduduk yang diperoleh dari data Potensi Desa. Variabel dalam analisis ini dibagi berdasarkan data aksesibilitas, fasilitas pendidikan, fasilitas kesehatan dan fasilitas ekonomi yang secara rinci ditunjukkan pada Tabel 1.

Tingkat perkembangan suatu wilayah ditetapkan dengan suatu tingkatan hierarki yang didasarkan pada nilai Indeks Perkembangan Desa (IPD). Tahapan yang digunakan dalam penentuan perkembangan wilayah dengan menggunakan analisis Skalogram adalah sebagai berikut:

a. merasionalisasikan data jarak (aksesibilitas) dan fasilitas. Data jarak diinverskan dengan rumus: $y=1 / x_{\mathrm{ij}}$, dimana $y$ adalah variabel baru dan $x_{\mathrm{ij}}$ adalah data jarak $j$ di wilayah $i$. Nilai $y$ yang tidak terdefinisikan (xij=0) akan dihitung dengan persamaan: $y=x_{\mathrm{ij}}$ (nilai maksimum) ditambah simpangan baku jarak $j$. Kemudian data fasilitas diubah menjadi data kapasitas per 1,000 penduduk dengan cara jumlah fasilitas $j$ di wilayah $i$ dibagi dengan jumlah penduduk di wilayah $I$ lalu dikalikan 1,000 . 
b. melakukan pembobotan terhadap data kapasitas dengan cara data kapasitas $j$ dibagi dengan bobot fasilitas $j$, dimana bobot fasilitas $j=$ jumlah total kapasitas $j$ dibagi dengan jumlah wilayah yang memiliki fasilitas $j$.

c. melakukan standardisasi data yang dilakukan terhadap variabel-variabel baru dari data jarak dan fasilitas (berbobot) dengan menggunakan rumus:

$$
y i j=\frac{X i j-(\operatorname{Min} X j)}{S j}
$$

dimana:

$y_{\mathrm{ij}} \quad=$ variabel baru untuk wilayah ke-i dan jenis fasilitas atau jarak ke-j

$x_{\mathrm{ij}} \quad=$ jumlah sarana untuk wilayah ke-i dan jenis sarana atau jarak ke-j

$\operatorname{Min}\left(x_{\mathrm{j}}\right)=$ nilai minimum untuk jenis sarana atau jarak ke-j

$\mathrm{S}_{\mathrm{j}} \quad=$ simpangan baku untuk jenis sarana atau jarak ke-j

a. menghitung nilai Indeks Perkembangan Desa (IPD) yang ditentukan dengan cara menghitung jumlah hasil standardisasi sarana dan aksesibilitas di setiap unit wilayah desa. Persamaan untuk menentukan nilai IPD adalah sebagai berikut:

$$
I P D_{\mathrm{j}}=\sum_{i=1}^{p} Y_{\mathrm{ij}}
$$

dimana:

IPD = Indeks perkembangan desa;

$Y_{\mathrm{ij}}=$ Jumlah jenis/unit fasilitas ke-i di wilayah ke-j

Tingkatan hierarki kemudian ditetapkan dengan kriteria sebagai berikut: (1) Hierarki I jika nilai IPD lebih besar dari nilai simpangan baku dan rerata IPD pada seluruh wilayah; (2) Hierarki II jika nilai IPD lebih besar atau sama dengan nilai rerata IPD pada seluruh wilayah dan (3) Hierarki III jika nilai IPD lebih kecil dari nilai rerata IPD pada seluruh wilayah.
Tabel 1. Variabel yang digunakan dalam analisis

\begin{tabular}{|c|c|}
\hline Jenis & Nama Variabel \\
\hline Aksesibilitas & $\begin{array}{l}\text { Jarak dari kantor Desa/Kelurahan } \\
\text { ke kantor Kecamatan yang } \\
\text { membawahi } \\
\text { Jarak dari kantor Desa/Kelurahan } \\
\text { ke kantor Kabupaten/Kota yang } \\
\text { membawahi } \\
\text { Jarak dari kantor Desa/Kelurahan } \\
\text { ke Ibu Kota Kabupaten/Kota lain } \\
\text { yang terdekat }\end{array}$ \\
\hline $\begin{array}{l}\text { Fasilitas } \\
\text { Pendidikan }\end{array}$ & $\begin{array}{l}\text { TK } \\
\text { SD/MI } \\
\text { SMP/MTs } \\
\text { SMA/MA } \\
\text { SMK } \\
\text { Akademi/Perguruan Tinggi } \\
\text { Sekolah Luar Biasa (SLB) } \\
\text { Pondok Pesantren Swasta/ } \\
\text { Madrasah Diniyah Swasta } \\
\text { Seminari/Sejenisnya } \\
\end{array}$ \\
\hline $\begin{array}{l}\text { Fasilitas } \\
\text { Kesehatan }\end{array}$ & $\begin{array}{l}\text { Rumah Sakit } \\
\text { Rumah Sakit bersalin } \\
\text { Puskesmas } \\
\text { Puskesmas pembantu } \\
\text { Poliklinik/balai pengobatan } \\
\text { Tempat praktek dokter } \\
\text { Tempat praktek bidan } \\
\text { Polindes (pondok bersalin desa) } \\
\text { Posyandu } \\
\text { Apotek }\end{array}$ \\
\hline $\begin{array}{l}\text { Fasilitas } \\
\text { Ekonomi }\end{array}$ & $\begin{array}{l}\text { Supermarket/Pasar } \\
\text { Swalayan/Toserba } \\
\text { Toko/Warung/Kios } \\
\text { Restoran/Rumah Makan/Kedai } \\
\text { Makanan Minuman } \\
\text { Hotel/Penginapan } \\
\text { Industri Kerajinan dari Kulit } \\
\text { Industri Kerajinan dari Kayu } \\
\text { Industri Kerajinan dari } \\
\text { Logam/Logam Mulia } \\
\text { Industri } \\
\text { Anyaman/Gerabah/Keramik } \\
\text { Industri Kerajinan dari Kain/Tenun } \\
\text { Industri Kerajinan Makanan } \\
\text { Bank Umum } \\
\text { Bank Pengkreditan Rakyat } \\
\text { Koperasi Unit Desa (KUD) }\end{array}$ \\
\hline
\end{tabular}
Skalogram 


\section{Analisis Perubahan Tutupan Lahan Tahun 2000 hingga 2015}

Proses analisis perubahan tutupan lahan dilakukan dengan menumpangtindihkan Citra Landsat tutupan lahan di wilayah penelitian tahun 2000 dan 2015 yang sebelumnya dilakukan konversi terlebih dahulu dari data raster menjadi data vektor. Citra Landsat tutupan lahan telah dikoreksi sistematik dan sudah diklasifikasi secara visual oleh Pusat Penelitian Lingkungan Hidup IPB. Tumpang tindih peta dilakukan menggunakan software ArcGIS 10.3 sehingga menghasilkan peta perubahan tutupan lahan di wilayah penelitian pada periode tahun 2000 hingga 2015. Hasil analisis tersebut kemudian digunakan untuk mendapatkan matriks perubahan tutupan lahan di wilayah penelitian pada periode tahun 2000 hingga 2015.

\section{Prediksi Penggunaan/ penutupan Lahan} Tahun 2030

Prediksi penggunaan/ penutupan lahan tahun 2030 dilakukan menggunakan Markov Chain Idrisi Selva dengan metode permodelan Cellular Automata melalui pembangunan dua model untuk menjalankan skema validasi CA Markov (Kurniawan et al., 2017; Saifullah et al., 2017), yaitu: Model 1 untuk memprediksi penggunaan/ penutupan lahan tahun 2015 dan Model 2 untuk memprediksi penggunaan/ penutupan lahan tahun 2030. Tahapan yang dilakukan dalam prediksi penggunaan/ penutupan lahan menggunakan CA Markov adalah sebagai berikut:

1. Menganalisis semua jenis perubahan penggunaan/ penutupan lahan yang terjadi antara tahun 2000 hingga 2015 (Model 1) dan tahun 2005 hingga 2015 (Model 2).

2. Membuat matriks probabilitas perubahan penggunaan/ penutupan lahan untuk memprediksi penggunaan/ penutupan lahan tahun 2015 dan tahun 2030 melalui analisis Markov Chain. Matriks probabilitas konversi menunjukkan besarnya peluang perubahan penggunaan lahan ke penggunaan lainnya dan jumlah piksel suatu penggunaan lahan yang diduga akan berubah menjadi penggunaan lainnya.

3. Memprediksi penggunaan/ penutupan lahan dan sensitivitas perubahan lahan tahun 2015 dan 2030 dengan input peta potensi konversi lahan yang dihasilkan pada tahap kedua serta matriks probabilitas konversi lahan yang dihasilkan pada tahap ketiga.

4. Validasi permodelan prediksi penggunaan/ penutupan lahan yang telah dibangun dengan cara membandingkan peta penggunaan/ penutupan lahan tahun 2015 dengan peta penggunaan lahan tahun 2015 aktual menggunakan panel validate pada Idrisi Selva (dikategorikan mempunyai akurasi yang baik apabila memiliki nilai $K$ standard minimal 0.85 ).

\section{HASIL DAN PEMBAHASAN}

\section{Perkembangan Wilayah}

Perkembangan suatu wilayah ditentukan oleh tingkat hierarki, dimana hierarki I yang berarti suatu wilayah tersebut sangat berkembang, hierarki II cukup berkembang dan hierarki III kurang berkembang. Tingkatan suatu hierarki dipengaruhi oleh besarnya nilai indeks perkembangan desa di wilayah tersebut. Semakin besar nilai indeks perkembangan desa di suatu wilayah, maka wilayah tersebut makin berkembang diiringi dengan hierarki yang semakin tinggi dan sebaliknya. Tingkatan hierarki di desa-desa pada Kabupaten Purwakarta dapat dilihat pada Tabel 2.

Desa-desa yang terdapat di Kabupaten Purwakarta yang berjumlah 192 desa mengalami dinamika peningkatan dan penurunan hierarki dari tahun 2003 hingga tahun 2014. Secara umum Kabupaten Purwakarta mengalami peningkatan perkembangan wilayah dalam kurun waktu 11 tahun yang ditandai dengan menurunnya persentase jumlah desa yang berhierarki III dari 62\% pada tahun 2003 menjadi 55.7\% pada tahun 2014 yang berarti berkurangnya jumlah 
desa-desa yang berada pada tingkatan kurang berkembang. Sebaliknya, persentase jumlah desa yang berhierarki II dan I mengalami peningkatan dimana masing-masing pada tahun 2003 sebesar $25.6 \%$ dan $12.4 \%$ meningkat pada tahun 2014 menjadi sebesar $29.6 \%$ dan $14.8 \%$ yang berarti bertambahnya jumlah desa-desa yang berada pada tingkatan cukup berkembang dan sangat berkembang. Peningkatan perkembangan wilayah yang terjadi di
Kabupaten Purwakarta dari tahun 2003 hingga 2014 sangat dipengaruhi oleh peningkatan jumlah penduduk sebesar 166,767 jiwa dari 720,249 jiwa pada tahun 2003 menjadi 887,016 jiwa pada tahun 2014. Peningkatan ini akan meningkatkan aktivitas pada suatu wilayah yang akan mendorong terjadinya penambahan jumlah dan jenis fasilitas di wilayah tersebut sehingga berakibat pada terjadinya perkembangan wilayah.

Tabel 2. Hasil analisis skalogram desa-desa di Kabupaten Purwakarta tahun 2003 dan 2014

\begin{tabular}{|c|c|c|c|c|c|c|}
\hline \multirow{2}{*}{ Nama Kecamatan } & \multicolumn{3}{|c|}{ Jumlah desa tahun 2003} & \multicolumn{3}{|c|}{ Jumlah desa tahun 2014} \\
\hline & Hierarki I & Hierarki II & Hierarki III & Hierarki I & Hierarki II & Hierarki III \\
\hline BABAKANCIKAO & 0 & 6 & 3 & 2 & 3 & 4 \\
\hline BOJONG & 5 & 3 & 6 & 2 & 3 & 9 \\
\hline BUNGURSARI & 2 & 6 & 2 & 4 & 2 & 4 \\
\hline CAMPAKA & 0 & 0 & 10 & 2 & 3 & 5 \\
\hline CIBATU & 0 & 2 & 8 & 3 & 4 & 3 \\
\hline DARANGDAN & 0 & 5 & 10 & 1 & 5 & 9 \\
\hline JATILUHUR & 3 & 2 & 5 & 1 & 3 & 6 \\
\hline KIARAPEDES & 0 & 1 & 9 & 0 & 2 & 8 \\
\hline MANIIS & 0 & 2 & 6 & 0 & 3 & 5 \\
\hline PASAWAHAN & 2 & 3 & 7 & 1 & 1 & 10 \\
\hline PLERED & 5 & 1 & 10 & 1 & 4 & 11 \\
\hline PONDOK SALAM & 0 & 5 & 6 & 0 & 3 & 8 \\
\hline PURWAKARTA & 5 & 3 & 2 & 5 & 2 & 3 \\
\hline SUKASARI & 0 & 0 & 5 & 0 & 3 & 2 \\
\hline SUKATANI & 1 & 5 & 8 & 0 & 2 & 12 \\
\hline TEGAL WARU & 0 & 3 & 10 & 3 & 2 & 8 \\
\hline WANAYASA & 3 & 2 & 10 & 3 & 10 & 2 \\
\hline $\begin{array}{l}\text { Kabupaten } \\
\text { Purwakarta }\end{array}$ & $26(12.4 \%)$ & $49(25.6 \%)$ & $117(62 \%)$ & $28(14.8 \%)$ & $55(29.6 \%)$ & $109(55.7 \%)$ \\
\hline
\end{tabular}

Perkembangan wilayah hasil analisis Skalogram Kabupaten Purwakarta secara spasial dapat dilihat pada Gambar 2. Desa-desa yang berada pada hierarki I umumnya berada dekat atau dilalui dengan jalur aksesibilitas utama seperti jalan tol, jalan provinsi dan jalan kabupaten. Pada tahun 2014 persentase jumlah desa-desa pada suatu kecamatan yang berada dekat atau dilalui dengan jalur aksesibilitas utama cenderung meningkat, seperti pada kecamatan Babakancikao, Bungursari, Campaka, Cibatu dan Tegal Waru. Peningkatan hierarki pada wilayah yang berada dekat atau dilalui dengan jalur aksesibilitas ini sesuai dengan pernyataan Tuloli (2012), yang menyatakan bahwa faktor aksesibilitas mempengaruhi perkembangan suatu wilayah secara spasial. Wilayah yang dilalui jalan/jalur transportasi (aksesibilitas) yang baik akan mengalami perkembangan fisik yang lebih baik terkait dengan tingkat kemudahan relatif suatu lokasi untuk mencapai suatu tempat tertentu karena adanya sarana dan prasarana yang mendukung.

Semakin padat dan kompleks jaringan jalan/jalur transportasi yang terdapat di Kabupaten Purwakarta, maka akan semakin tinggi tingkat aksesibilitas dan kemampuan berinteraksi antarwilayahnya. Hal inilah yang menyebabkan terjadinya transformasi wilayah di Kabupaten Purwakarta dari sifat kedesaan menjadi kekotaan yang cenderung lebih jelas terlihat pada daerah di sepanjang jalur transportasi atau jaringan jalan yang padat. 


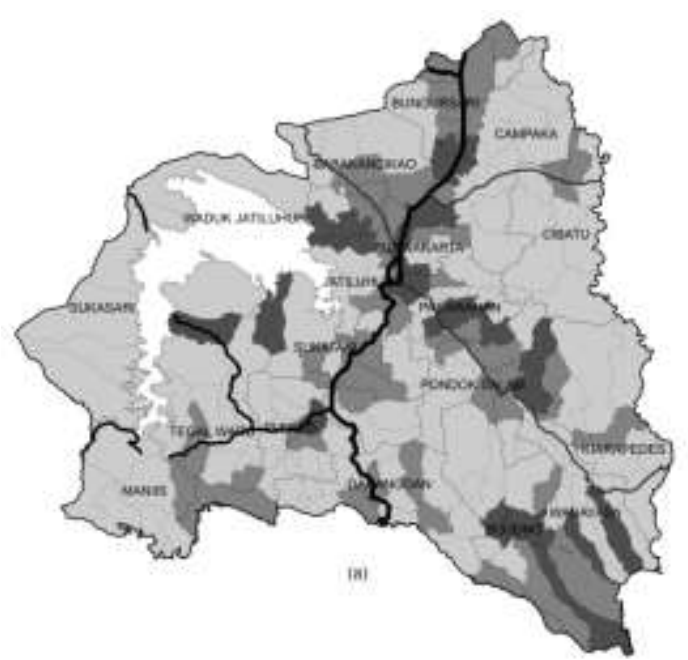

Legenda

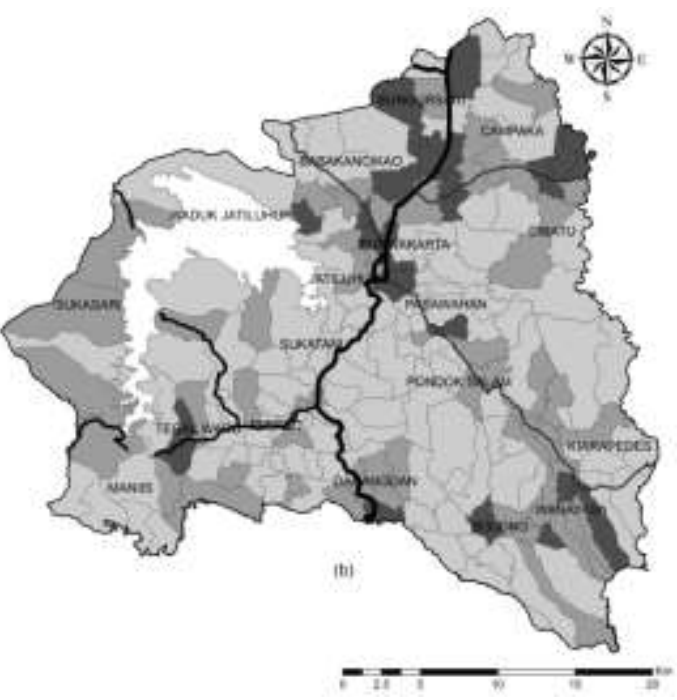

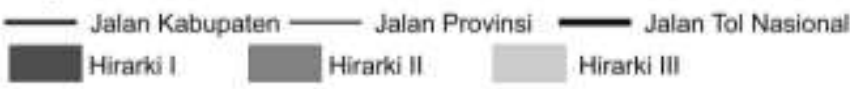

Gambar 2. Sebaran spasial hierarki di Kabupaten Purwakarta: (a) tahun 2003 dan (b) tahun 2014

\section{Perubahan Tutupan Lahan tahun 2000 hingga 2015}

Jenis tutupan lahan pada Citra Landsat yang telah dikoreksi sistematik dan sudah diklasifikasi secara visual oleh Pusat Penelitian Lingkungan Hidup IPB adalah Lahan Terbangun (LT), Lahan Terbuka (LTbk), Hutan (H), Kebun Campuran (KC), Sawah (S) dan Badan Air (BA). Luas tutupan lahan di Kabupaten Purwakarta pada tahun 2000 dan 2015 ditampilkan pada Tabel 3. Secara umum dalam kurun waktu 15 tahun Kabupaten Purwakarta mengalami peningkatan luas tutupan lahan terbangun dan kebun campuran, sedangkan lahan terbuka, hutan, sawah dan badan air mengalami penyusutan luas. Pada tahun 2015 lahan terbangun mengalami peningkatan luas yang sangat besar yaitu sekitar 210\% dari luasan awal pada tahun 2000.

Peningkatan lahan terbangun yang sangat besar di Kabupaten Purwakarta ini sesuai dengan pernyataan Giyarsih (2012), yang menyatakan bahwa wilayah pada koridor yang menghubungkan dua kota besar akan menyebabkan semakin kaburnya (blurring) sifat perdesaan dan semakin kuatnya sifat perkotaan yang ditandai dengan kotadesasi dimana struktur wilayah agraris yang dominan lahan-lahan bervegetasi akan berubah menjadi struktur non-agraris yang dominan pada lahanlahan terbangun. Peningkatan jumlah penduduk juga menjadi salah satu faktor yang mempengaruhi perubahan lahan-lahan bervegetasi menjadi lahan-lahan terbangun (Prasetyo et al., 2016).

Tabel 3. Luas tutupan lahan di Kabupaten Purwakarta tahun 2000 hingga 2015 (ha)

\begin{tabular}{lllll}
\hline \multirow{2}{*}{ Jenis Tutupan Lahan } & \multirow{2}{*}{ Tahun 2000 } & \multirow{2}{*}{ Tahun 2015 } & Perubahan & \\
\cline { 4 - 5 } & & & ha & $\%$ \\
\hline LT & $3,116.89$ & $9,681.56$ & $6,564.68$ & 210.62 \\
LTbk & $3,792.25$ & $3,197.63$ & -594.62 & -15.68 \\
H & $8,265.08$ & $8,250.61$ & -14.47 & -0.18 \\
KC & $43,427.00$ & $45,118.75$ & $1,691.75$ & 3.90 \\
S & $31,052.40$ & $24,909.82$ & $-6,142.59$ & -19.78 \\
BA & $7,445.88$ & $5,926.67$ & $-1,519.21$ & -20.40 \\
\hline
\end{tabular}



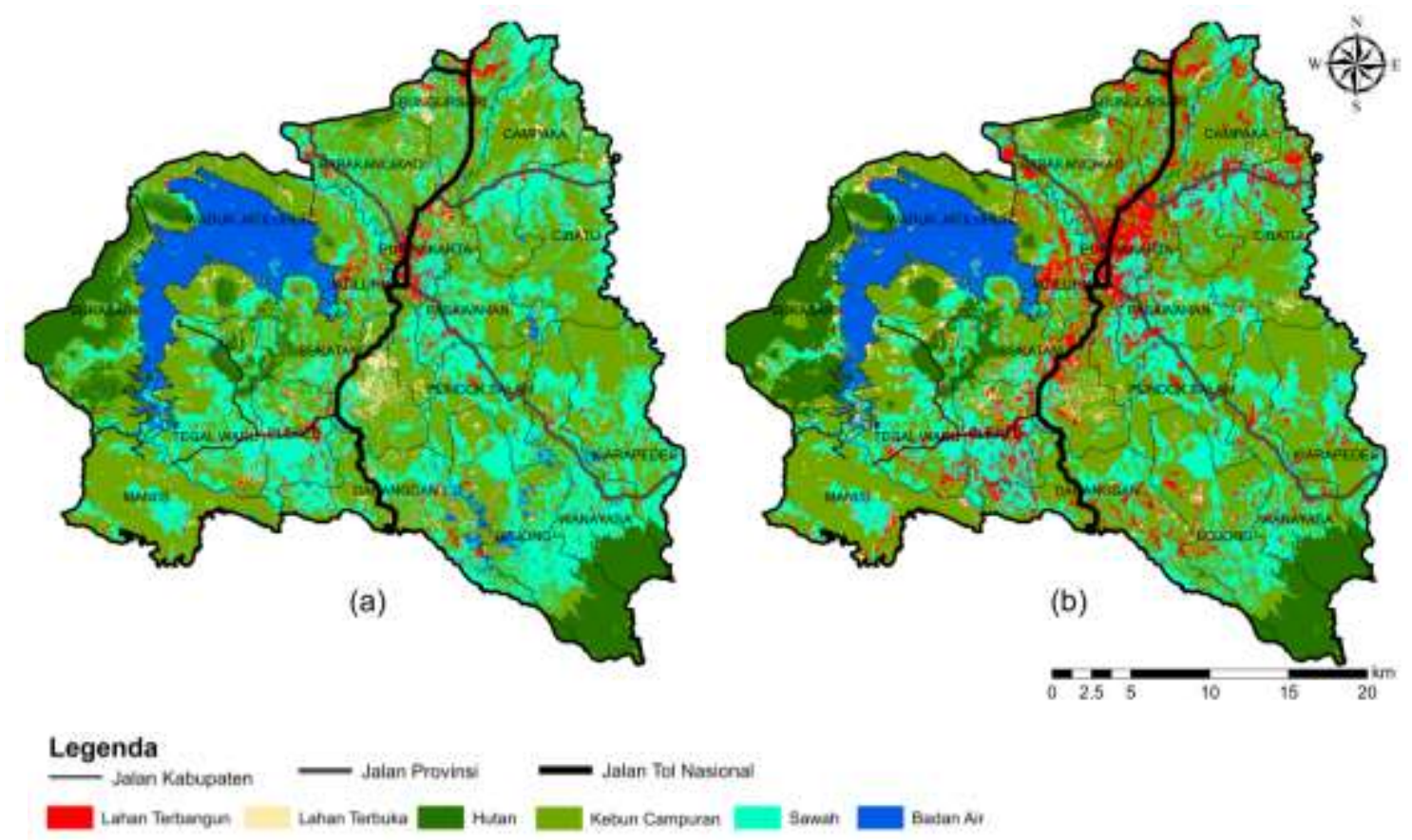

Gambar 3. Tutupan lahan: (a) tahun 2000 dan (b) tahun 2015

Kabupaten Purwakarta yang berada pada koridor mega-urban Jakarta-Bandung secara spasial akan terkena dampak kota metropolitan dengan semakin berkembangnya lahan-lahan terbangun. Gambar 4 menunjukkan bahwa sebagian besar peningkatan lahan terbangun cenderung terjadi pada wilayah-wilayah yang berada dekat atau dilalui dengan jalur aksesibilitas utama seperti jalan tol, jalan provinsi dan jalan kabupaten. Tren kecenderungan peningkatan lahan terbangun ini sesuai dengan pernyataan Susanti (2013), yang menyatakan bahwa semakin baik dan semakin kompleks suatu infrastruktur jalan akan mengakibatkan terbentuknya pusat-pusat kegiatan dan fungsi-fungsi perkotaan baru yang berada sepanjang kiri kanan jalur transportasi jalan yang ada. Hal ini menyebabkan kecenderungan terjadinya alih fungsi lahan bervegetasi menjadi lahan terbangun seperti kawasan permukiman, perdagangan, maupun industri di sekitar jalur transportasi.

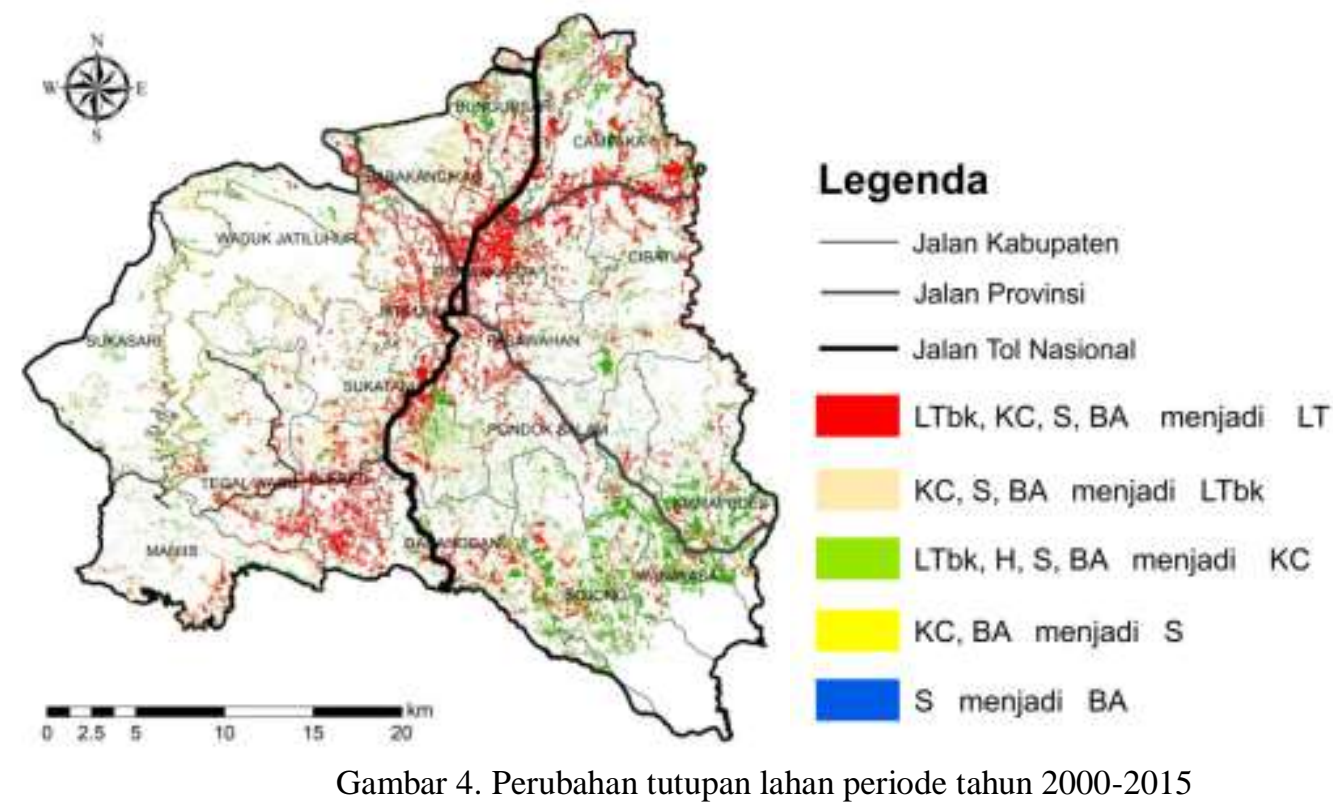


Luas perubahan tutupan lahan di Kabupaten Purwakarta dari tahun 2000 hingga 2015 dapat dilihat pada Tabel 4. Total perubahan yang terjadi dalam kurun waktu 15 tahun paling besar terjadi pada sawah, kebun campuran dan lahan terbuka yang masingmasing mengalami perubahan seluas 6,222.20 ha, 5,566.22 ha dan 3,138.88 ha. Badan air mengalami perubahan seluas $1,532.30$ ha dimana pada umumnya perubahan yang terjadi merupakan pembangunan lahan terbangun seperti permukiman di pinggir sungai maupun pemanfaatan pinggiran sungai sebagai lahan pertanian seperti sawah atau kebun campuran. Badan air seperti sungai juga dapat berubah menjadi lahan terbuka karena terjadinya proses sedimentasi yang menyebabkan menurunnya kualitas lingkungan pada daerah sungai tersebut (Soewandita, 2017).

Tabel 4. Matriks perubahan tutupan lahan di Kabupaten Purwakarta periode tahun 2000-2015 (ha)

\begin{tabular}{|c|c|c|c|c|c|c|c|}
\hline \multirow{2}{*}{$\begin{array}{c}\text { Tutupan Lahan } \\
\text { tahun } 2000\end{array}$} & \multicolumn{6}{|c|}{ Tutupan Lahan tahun 2015} & \multirow{2}{*}{$\begin{array}{c}\text { Total } \\
\text { Perubahan }\end{array}$} \\
\hline & LT & LTbk & $\mathrm{H}$ & $\mathrm{KC}$ & $\mathrm{S}$ & BA & \\
\hline LT & $3,116.89$ & & & & & & \\
\hline LTbk & $1,472.66$ & 653.37 & & $1,666.22$ & & & $3,138.88$ \\
\hline $\mathrm{H}$ & & & $8,250.61$ & 14.47 & & & 14.47 \\
\hline $\mathrm{KC}$ & $3,446.09$ & $2,072.04$ & & $37,860.78$ & 48.09 & & $5,566.22$ \\
\hline S & $1,406.25$ & 357.95 & & $4,444.92$ & $24,830.20$ & 13.09 & $6,222.20$ \\
\hline BA & 239.67 & 114.27 & & $1,146.83$ & 31.52 & $5,913.58$ & $1,532.30$ \\
\hline
\end{tabular}

Hutan hanya mengalami perubahan seluas 14.47 ha menjadi kebun campuran. Menurut Ruswandi et al. (2007), hutan dapat berubah menjadi kebun campuran karena masyarakat dan petani di wilayah sekitar hutan pada umumnya membuka lahan pertanian yang termasuk kategori kebun campuran dengan cara membuka hutan. Tutupan lahan terbuka mengalami perubahan sebesar 3,138.88 ha dari tahun 2000 hingga 2015. Sebesar 46.91\% lahan terbuka berubah menjadi lahan terbangun yang didominasi oleh kawasan permukiman. Hasil ini selaras dengan penelitian Setiawan et al., (2016) yang menyatakan bahwa berkurangnya lahan terbuka terjadi karena intensifnya pemanfaatan lahan terbuka tersebut untuk dijadikan kawasan pemukiman. Perubahan tutupan lahan sawah dan kebun campuran cukup mendominasi, menurut Pribadi (2018) perubahan tutupan lahan pertanian memiliki kerugian sebagai dampak dari peningkatan pertumbuhan penduduk dan aktivitas sosialekonomi yang dapat dikategorikan sebagai sebuah bencana. Perubahan tutupan lahan pertanian juga dapat terjadi akibat tekanan urbanisasi.
Secara umum kebun campuran merupakan tutupan lahan yang paling banyak berubah menjadi lahan terbangun, yaitu seluas 3,446.09 ha, diikuti dengan lahan terbuka, sawah dan badan air yang masing-masing seluas $1,472.66$ ha; $1,406.25$ ha dan 239.67 ha. Tutupan-tutupan lahan yang telah mengalami perubahan tersebut sangat sulit untuk diubah kembali menjadi tutupan sebelumnya. Hal ini sesuai dengan pernyataan Rustiadi et al. (2011), yang menyatakan bahwa alih fungsi lahan umumnya bersifat irreversible atau tidak dapat kembali. Lahan-lahan bervegetasi yang terutama telah berubah menjadi lahan terbangun sangat sulit untuk diubah kembali menjadi lahan bervegetasi.

\section{Prediksi Penggunaan/ penutupan Lahan Tahun 2030}

Penutupan lahan diperkirakan setiap tahun akan mengalami dinamika perubahan sehingga perlu dilakukan prediksi penutupan lahan yang akan datang agar dapat dilakukan pengendalian. Munibah (2008) menyatakan bahwa salah satu alat yang dapat digunakan untuk memprediksi kondisi penutupan lahan 
berdasarkan tren perubahan penutupan lahan adalah permodelan dengan pendekatan model Cellular Automata (CA). Penentuan prediksi penggunaan/ penutupan lahan tahun $2030 \mathrm{di}$ Kabupaten Purwakarta dilakukan dengan menjadikan peta penggunaan lahan tahun 2000 sebagai tahun dasar dan tahun 2015 sebagai tahun kedua dalam analisis CA Markov dengan jumlah iterasi sebanyak 15 kali sehingga dapat terlihat pada matriks probabilitas dan matriks transisi areanya. Semakin tinggi nilai diagonal yang ditunjukkan pada matriks probabilitas maka diperkirakan peluang perubahan penggunaan/ penutupan lahan yang mungkin terjadi semakin rendah atau tidak mudah berubah menjadi penggunaan/ penutupan lahan yang lain, namun jika semakin rendah nilainya maka peluang perubahan akan semakin besar. Matriks probabilitas dan matriks transisi area hasil analisis CA Markov tersaji pada Tabel 5. Probabilitas perubahan penggunaan/ penutupan lahan prediksi tahun 2030 menunjukan bahwa LT dan $\mathrm{H}$ cenderung tidak mempunyai peluang akan mengalami perubahan ke penggunaan lahan lainnya, namun LTbk, KC, S dan BA cenderung mempunyai peluang akan mengalami perubahan ke penggunaan lahan lainnya.

Tabel 5. Matriks probabilitas perubahan penggunaan/ penutupan lahan prediksi tahun 2030

\begin{tabular}{lllllll}
\hline & LT & LTbk & H & KC & S & BA \\
\hline LT & 0.8500 & 0.0300 & 0.0300 & 0.0300 & 0.0300 & 0.0300 \\
LTbk & 0.3994 & 0.1460 & 0.0000 & 0.4546 & 0.0000 & 0.0000 \\
H & 0.0000 & 0.0000 & 0.8487 & 0.1513 & 0.0000 & 0.0000 \\
KC & 0.1605 & 0.0965 & 0.0000 & 0.7409 & 0.0020 & 0.0000 \\
S & 0.0720 & 0.0187 & 0.0000 & 0.2283 & 0.6803 & 0.0007 \\
BA & 0.0513 & 0.0242 & 0.0000 & 0.2426 & 0.0068 & 0.6751 \\
\hline
\end{tabular}

Luas tutupan lahan tahun 2030 hasil analisis CA Markov disajikan pada Tabel 6 . Tabel tersebut menunjukkan bahwa jenis tutupan lahan yang mengalami peningkatan luas dari tahun 2015 hingga tahun 2030 adalah lahan terbangun dan lahan terbuka. Lahan terbangun mengalami peningkatan luas lebih dari dua kali lipat dari luasan awal pada tahun 2015 yaitu sebesar $108.50 \%$. Sedangkan jenis tutupan lahan hutan, kebun campuran, sawah dan badan air mengalami penyusutan luas.

Sebaran spasial perubahan penggunaan/ penutupan lahan tahun 2015 hingga 2030 disajikan pada Gambar 5. Gambar tersebut menunjukkan bahwa pada tahun 2015 hingga 2030 terjadi tren kecenderungan perubahan yang sama seperti perubahan pada tahun 2000 hingga 2015, dimana sebagian besar peningkatan lahan terbangun cenderung terjadi pada wilayah-wilayah yang berada dekat atau dilalui dengan jalur aksesibilitas utama seperti jalan tol, jalan provinsi dan jalan kabupaten. Menurut Peter dan Glenn, (2014) dalam Kurnianti et al., (2015), setelah tahun 1980 kejadian urban expansion yang menyebabkan peningkatan lahan-lahan terbangun terjadi pada lokasi yang berada dekat dengan lahan terbangun yang sudah ada dan jalan-jalan besar seperti arteri, karena aksesibilitas menjadi salah satu pertimbangan penting dalam memilih lokasi untuk pembangunan suatu lahan terbangun.

Tabel 6. Luas tutupan lahan di Kabupaten Purwakarta tahun 2015 (aktual) dan 2030 (proyeksi) (ha)

\begin{tabular}{lllrr}
\hline \multirow{2}{*}{ Jenis Tutupan Lahan } & \multirow{2}{*}{ Tahun 2015 (aktual) } & \multirow{2}{*}{ Tahun 2030 (proyeksi) } & \multicolumn{2}{c}{ Perubahan } \\
\cline { 3 - 5 } & & & \multicolumn{1}{c}{ ha } & \% \\
\hline LT & $9,681.56$ & $20,186.45$ & $10,504.88$ & 108.50 \\
LTbk & $3,197.63$ & $5,379.26$ & $2,181.64$ & 68.23 \\
H & $8,250.61$ & $7,031.28$ & $-1,219.33$ & -14.78 \\
KC & $45,118.75$ & $43,362.51$ & $-1,770.71$ & -3.92 \\
S & $24,909.82$ & $17,161.35$ & $-7,748.46$ & -31.11 \\
BA & $5,926.67$ & $4,039.62$ & $-1,887.05$ & -31.84 \\
\hline
\end{tabular}



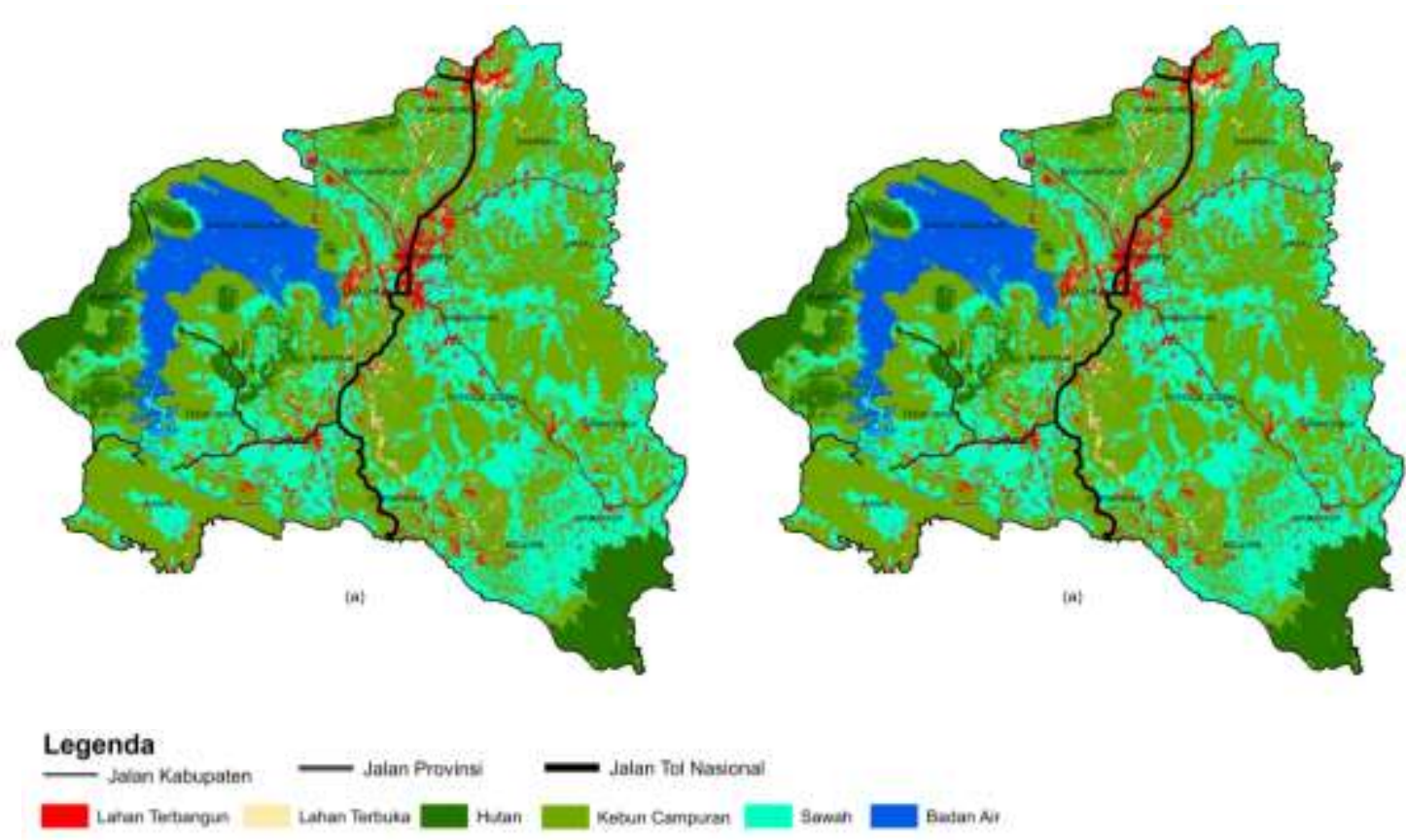

Gambar 5. Proyeksi penggunaan/ penutupan lahan: (a) tahun 2015 dan (b) tahun 2030

Proses perubahan penggunaan/ penutupan lahan yang terjadi pada Kabupaten Purwakarta terutama perubahan menjadi lahan terbangun yang sangat tinggi merupakan salah satu dampak dari terjadinya proses konurbasi Jakarta-Bandung. Menurut Firman (2009), peningkatan lahan terbangun seperti permukiman dan infrastruktur pada wilayah metropolitan Jakarta, Bandung dan wilayah sekitarnya merupakan salah satu faktor yang mengakibatkan berkembangnya wilayahwilayah tersebut sehingga terjadi proses pembentukan wilayah mega-urban JakartaBandung.

Berkembangnya wilayah koridor yang melibatkan berbagai satuan wilayah administratif ini menyebabkan perlunya setiap satuan wilayah administratif yang dalam hal ini adalah pemerintah kabupaten/kota untuk melakukan kerjasama dan koordinasi dalam berbagai bidang untuk mencapai tujuan pembangunan yang optimal. Giyarsih (2012) menyebut kerjasama dan koordinasi antar pemerintah kabupaten/kota ini sebagai tindakan sinergisme spasial dan sinergisme fungsional. Sinergisme spasial merupakan suatu bentuk koordinasi antarwilayah yang dapat menimbulkan dampak positif lebih baik dibandingkan antarwilayah tersebut berdiri dan berjalan sendiri-sendiri. Sementara sinergisme fungsional merupakan bentuk koordinasi antarwilayah yang menguntungkan berbagai instansi baik pemerintah maupun swasta yang berada di masing-masing wilayah administratif yang tergabung dalam suatu bentuk kerjasama regional dibandingkan antarwilayah tersebut bekerja sendiri-sendiri. Dalam hal ini, Kabupaten Purwakarta baik dari instansi pemerintah maupun swasta perlu melakukan tindakan sinergisme spasial dan sinergisme fungsional dengan wilayah-wilayah kabupaten/kota di sekitarnya sepanjang koridor Jakarta-Bandung agar tidak terjadi perkembangan wilayah yang tidak merata atau terjadinya ketimpangan antardaerah demi mewujudkan tujuan pembangunan yang optimal.

\section{SIMPULAN}

1. Kabupaten Purwakarta mengalami perkembangan wilayah dalam kurun waktu 11 tahun (2003 hingga 2014) yang ditandai dengan menurunnya persentase jumlah desa yang berhierarki III dan meningkatnya persentase jumlah desa yang berhierarki II dan I. Desa-desa yang berada pada hierarki I umumnya berada dekat atau dilalui dengan jalur 
aksesibilitas utama seperti jalan tol, jalan provinsi dan jalan kabupaten.

2. Kabupaten Purwakarta dalam kurun waktu 15 tahun (2000 hingga 2015) mengalami peningkatan luas tutupan lahan terbangun dan kebun campuran, sedangkan lahan terbuka, hutan, sawah dan badan air mengalami penyusutan luas. Lahan terbangun mengalami peningkatan luas yang sangat besar yaitu sekitar $210 \%$ dari luasan awal pada tahun 2000. Sebagian besar peningkatan lahan terbangun cenderung terjadi pada wilayah-wilayah yang berada dekat atau dilalui dengan jalur aksesibilitas utama seperti jalan tol, jalan provinsi dan jalan kabupaten.

3. Hasil analisis permodelan CA Markov menunjukkan bahwa pada tahun 2030 diprediksi jenis tutupan lahan yang mengalami peningkatan luas dari tahun 2015 adalah lahan terbangun dan lahan terbuka. Sedangkan jenis tutupan lahan hutan, kebun campuran, sawah dan badan air mengalami penyusutan luas. Hasil prediksi menunjukkan bahwa pada tahun 2015 hingga 2030 terjadi tren kecenderungan perubahan yang sama seperti perubahan pada tahun 2000 hingga 2015, dimana kecenderungan ini terjadi karena aksesibilitas menjadi salah satu pertimbangan penting dalam memilih lokasi untuk pembangunan suatu lahan terbangun.

\section{DAFTAR PUSTAKA}

Abror, S. M., Purwoko, A., \& Pratomo, W. A. (2016). Analisis Pengaruh Pembangunan Jaringan Jalan terhadap Perubahan Guna Lahan di Kawasan Aek Kanopan. Jurnal Ekonom, 19 (2), 82-89

Bunnel, T., Barter, P. A., \& Morshidi, S. (2002). City Profile Kuala Lumpur Metropolitan Area. Cities, 19 (5), 357 370
Dorodjatoen, A. M. H. (2009). The Emergence of Jakarta-Bandung Mega Urban Region and It's Future Challenges. Jurnal Perencanaan Wilayah dan Kota, 20 (1), 15-33

Ekosafitri, K. H., Rustiadi, E., \& Yulianda, F. (2017). Pengembangan Wilayah Pesisir Pantai Utara Jawa Tengah Berdasarkan Infrastruktur Daerah: Studi Kasus Kabupaten Jepara. Journal of Regional and Rural Development Planning, 1 (2), 145-157

Firman, T. (2009). The Continuity and Change in Mega-urbanization in Indonesia: A Survey of Jakarta-Bandung Region (JBR) Development. Habitat International, 33 (2009), 327-339

Giyarsih, S. R. (2012). Koridor Antar Kota sebagai Penentu Sinergisme Spasial: Kajian Geografi yang Semakin Penting. TATALOKA, 14 (2), 90-97

Kurnianti, D. N., Rustiadi, E., \& Baskoro, D. P. T. (2015). Land Use Projection for Spatial Plan Consistency in Jabodetabek. Indonesian Journal of Geography, 47 (2), 124-131

Kurniawan, I., Barus, B., \& Pravitasari, A. E. (2017). Pemodelan Spasial Perubahan Penggunaan Lahan di Taman Nasional Gunung Halimun Salak dan Daerah Penyangganya. Journal of Regional and Rural Development Planning, 1(3), 270286

Munibah, K. (2008). Model Spasial Perubahan Penggunaan Lahan dan Arahan Penggunaan Lahan Berwawasan Lingkungan (Studi Kasus DAS Cidanau, Provinsi Banten). Disertasi. Institut Pertanian Bogor

Peraturan Menteri Pekerjaan Umum No. 494 Tahun 2005 tentang Kebijakan dan Strategi Nasional Pengembangan Perkotaan

Prasetyo, A., Koestoer, R. H., \& Waryono, T. (2016). Pola Spasial Penjalaran Perkotaan Bodetabek: Studi Aplikasi Model Shannon's Entropy. Jurnal Pendidikan Geografi, 16(2), 144-160 
Pravitasari, A. E., Saizen, I., Tsutsumida, N., Rustiadi, E., \& Pribadi, D. O. (2015). Local Spatially Dependent Driving Forces of Urban Expansion in an Emerging Asian Megacity: the Case of Greater Jakarta (Jabodetabek). Journal of Sustainable Development, 8 (1), 108-119

Pravitasari, A. E., Rustiadi, E., Mulya, S. P., Setiawan, Y., Fuadina, L. N., \& Murtadho, A. (2018). Identifying the Driving Forces of Urban Expansion and its Environmental Impact in JakartaBandung Mega Urban Region. IOP Conference Series: Earth and Environmental Science, 149 (2018), 1-10

Pribadi, D. O., Vollmer, D., \& Pauleit, S. (2018). Impact of Peri-urban Agriculture on Runoff and Soil Erosion in the Rapidly Developing Metropolitan Area of Jakarta, Indonesia. Springer-Verlag GmbH Germany

Rustiadi, E., Saefulhakim, S., \& Panuju, D. R. (2011). Perencanaan dan Pengembangan Wilayah, 58-114. Yayasan Pustaka Obor

Ruswandi, A., Rustiadi, E., \& Mudikdjo, K. (2007). Konversi Lahan Pertanian dan Dinamika Perubahan Penggunaan Lahan di Kawasan Bandung Utara. Jurnal Tanah dan Lingkungan, 9(2), 63-70

Saifullah, K., Barus, B., \& Rustiadi, E. (2017). Spatial Modelling of Land Use/Cover Change (LUCC) in South Tangerang City, Banten. IOP Conf., 54(1), 1-11

Setiawan, G., Syaufina, L., \& Puspaningsih, N. (2016). Pendugaan Hilangnya Cadangan Karbon dari Perubahan Penggunaan Lahan di Kabupaten Bogor. Jurnal Silvikultur Tropika, 7(2), 79-85

Sitorus, S. R. P., Leonataris, C., \& Panuju, D. R. (2012). Analisis Pola Perubahan Penggunaan Lahan dan Perkembangan Wilayah di Kota Bekasi, Provinsi Jawa Barat. J. Tanah Lingkungan, 14(1), 21-28 Soewandita, H. (2017). Studi Ekologi Lahan Koridor Sungai dan Status Kualitas Penggunaan Lahan di Wilayah DAS Rawapening. Jurnal Alami, 1(1), 33-42
Susanti, I. S. (2013). Pengaruh Perkembangan Pembangunan Infrastruktur Jalan terhadap Pertumbuhan Pemanfaatan Lahan Kota. Jurnal Rekayasa, 17(1), 4957

Tuloli, M. Y. (2012). Pengaruh Faktor Aksesibilitas (Jalan) terhadap Perkembangan Kota Gorontalo. Jurnal Teknik, 10(1), 32-42

Wilonoyudho, S. (2010). Urbanisasi dan Dampak Lingkungan di Koridor KendalSemarang-Demak. J. Manusia dan Lingkungan, 17(3), 173-182 